\title{
Drug Hypersensitivity
}

Diagnosis, Genetics, and Prevention

by Dr. med. Ruwen Böhm, Prof. Dr. med. Dr. rer. nat. Ehrhardt Proksch, Prof. Dr. med. Thomas Schwarz, and Prof. Dr. med. rer. nat. Ingolf Cascorbi in issue 29-30/2018

\section{New Classification}

With regard to the classification used in the article (1), it should be added that adverse drug reactions (ADRs) are increasingly no longer classified as type $\mathrm{A}$ and type $\mathrm{B}$ reactions (this classification originates from 1977 [2]), but rather as off-target and on-target reactions (3). The decision criterion here is whether or not an ADR is related to the pharmacological effect of a drug at its target site. Broadly speaking, off-target reactions (such as certain infusion reactions to biologics) correspond in a broader sense to type B reactions, whereas type A reactions are a kind of on-target reaction. The background to this is that also type A reactions may depend on individual genetic factors, and certain type $\mathrm{B}$ reactions can also be dose-dependent and predictable (3).

Regarding the pathophysiology of non-allergic hypersensitivity reactions, a 2015 Nature paper described a mast cell receptor in both a mouse model and human mast cells, which could be responsible for the IgE-independent release of histamine from mast cells (for instance, due to neuromuscular blocking agents, such as atracurium) (4).

\section{In Reply:}

We thank Prof. Sachs for his interest in our article (1). With respect to the alternative classification of adverse drug reactions (ADRs) as on- and off-target effects rather than the widely used type A and type B ARDs, it is true that the name assignment (with type B for "bizarre") does in fact seem blurred at times. We appreciate the provided example of the MRGPRX2 receptor, which is activated not only by the mentioned substances of muscle relaxants and gyrase inhibitors but also by vancomycin, thereby leading to mast cell degranulation. This example impressively shows that having a better understanding of molecular biology rapidly allows an ADR that had been classified until now as type B (e.g., red man syndrome after vancomycin) to be re-interpreted as a type A ADR (classical receptor-mediated pharmacological response). Consequently, the percentage of type B ADRs is increasingly being reduced, from about $20 \%$ in 1968 to about $9 \%$ in 2002 (2). The A/B scheme is nevertheless used worldwide and is also being further developed (types $\mathrm{C}-\mathrm{E}$ ). The dose-time-susceptibility classification system presents an additional attempt at subdivision (3). The alternative classification of ADRs into on-target and off-target also has weaknesses and unfortunately still does not address all issues.

The definitions of ADRs according to the German Medicines Act and Good Clinical Practice are not in contradiction to our
Contrary to an adverse event, the definition of an ADR is based on the suspected causal relationship with the use of a medicinal product (§4 [13] German Medicines Act, and §3 [6] GCP Regulation). For example, an accidental leg fracture may constitute an adverse event that occurs when using a medicinal product without necessarily being causally related to the use of the medicinal product.

DOI: 10.3238/arztebl.2018.0713a

\section{References}

1. Böhm R, Proksch E, Schwarz T, Cascorbi I: Drug hypersensitivitydiagnosis, genetics, and prevention. Dtsch Arztebl Int 2018; 115: 501-1.

2. Rawlins MD, Thompson JW: Pathogenesis of adverse drug reactions. In: Davies DM, eds.: Textbook of adverse drug reactions. Oxford, Oxford University Press 1977; 10-17.

3. Garon SL, Pavlos RK, White KD, Brown NJ, Stone CA Jr, Phillips EJ: Pharmacogenomics of off-target adverse drug reactions. Br J Clin Pharmacol 2017; 83: 1896-1911.

4. McNeil BD, Pundir P, Meeker S, et al.: Identification of a mast-cell-specific receptor crucial for pseudo-allergic drug reactions. Nature 2015. 519: 237-41.

\section{Prof. Dr. med. Bernhardt Sachs}

Bundesinstitut für Arzneimittel und Medizinprodukte

Abteilung Forschung, Bonn, Germany

Bernhardt.Sachs@bfarm.de

article. While we focus particularly on pharmacological effects, the legislator places causality — which indeed exists with a pharmacological effect - in the foreground. Depending on the application, there are various definitions of adverse events and ADRs (4).

DOI: 10.3238/arztebl.2018.0713b

\section{References}

1. Böhm R, Proksch E, Schwarz T, Cascorbi I: Drug hypersensitivity—diagnosis, genetics, and prevention. Dtsch Arztebl Int 2018; 115: 501-1.

2. Böhm R, Cascorbi I: Pharmacogenetics and predictive testing of drug hypersensitivity reactions. Front Pharmacol 2016; 7: 396.

3. Aronson JK, Ferner RE: Joining the DoTS: New approach to classifying adverse drug reactions. BMJ 2003; 327: 1222-5.

4. WHO. The conceptual framework for the international classification for patient safety version 1.1 Technical annex 2 Glossary of patient safety concepts and references. www.who.int/patientsafety/taxonomy/icps_technical_annex2.pdf. (last accessed on 20 September 2018)

\section{Dr. med. Ruwen Böhm}

Prof. Dr. med. Dr. rer. nat. Ingolf Cascorbi

Institut für Experimentelle und Klinische Pharmakologie

Universitätsklinikum Schleswig-Holstein, Campus Kiel, Germany

cascorbi@pharmakologie.uni-kiel.de

Prof. Dr. med. Dr. rer. nat. Ehrhardt Proksch

Prof. Dr. med. Thomas Schwarz

Klinik für Dermatologie, Venerologie und Allergologie

Universitätsklinikum Schleswig-Holstein, Campus Kiel, Germany

Conflict of interest statement

The authors of all contributions declare that no conflict of interest exists. 